\title{
Derivation of Crop Coefficient Model of Wheat and Maize Using Growing Degree Days to Mitigate Climatic Variability
}

\author{
Jeetendra Kumar ${ }^{1^{*}}$, U. N. Umesh ${ }^{2}$ and A. K. P. Singh ${ }^{3}$ \\ ${ }^{1}$ Krishi Vigyan Kendra, Jehanabad, BAU, Sabour (Bihar), India, \\ ${ }^{2}$ Krishi Vigyan Kendra, Harnaut, Nalanda, BAU, Sabour (Bihar), India, \\ ${ }^{3}$ Ex-Dean, Faculty of Agricultural Engineering, DRPCAU, Pusa (Bihar), India \\ *Corresponding author
}

\section{A B S T R A C T}

\section{Keywords}

Climate change, Crop coefficient, Growing degree day, Heat use efficiency, Temperature

\section{Article Info}

Accepted: 24 September 2020 Available Online: 10 October 2020
An experiment was carried out to develop crop coefficient model for estimation of crop evapotranspiration as a function of cumulative growing degree days of wheat (Triticum aestivum L.) and Maize (Zea mays L.). Crop coefficient values were calculated as ratio of crop evapotranspiration and reference evapotranspiration in which crop evapotranspiration for different periods of the growing season were determined using root zone water balance technique whereas reference evapotranspiration was estimated as the product of pan evaporation and appropriate values of pan coefficient for the period concerned. Daily maximum and minimum temperature data were used to calculate growing degree days (GDD) using base temperature of $5^{\circ} \mathrm{C}$ and $10^{\circ} \mathrm{C}$ with an upper threshold temperature of $25^{\circ} \mathrm{C}$ and $30^{\circ} \mathrm{C}$, respectively for wheat and maize and cumulative GDD were calculated for different periods of crop season. Total GDD to attain maturity of wheat and maize were found as $1906.6^{\circ} \mathrm{C}$-day and $1868.0^{\circ} \mathrm{C}$-day, respectively. Polynomial function was fitted to the crop coefficient values plotted against cumulative growing degree days (CGDD) of wheat and maize in which fourth order polynomial equation was found to be best fit with high value of coefficient of determination. Using these equations, crop coefficient values for any cumulative growing degree days after crop sowing can be computed for estimation of crop evapotranspiration of these crops for better irrigation water management in climate change perspective. The agro-meteorological index like heat use efficiency (HTU) and photo thermal index (PTI) were also calculated as weather based parameters for assessing crop phenology.

\section{Introduction}

Climate affects all the physiological processes of plant life. Since, water resources are being scarce for use as irrigation water, it should be applied efficiently. For better crop production, adequate and timely supply of water is required throughout the growing season according to evapotranspiration need of the crops. The crop evapotranspiration (consumptive use) estimates require specific values of crop coefficient for a particular crop. Crop coefficients are the empirical ratios of crop evapotranspiration $\left(\mathrm{ET}_{\mathrm{c}}\right)$ to estimated or measured reference evapotranspiration $\left(\mathrm{ET}_{\mathrm{o}}\right)$ (Doorenbos and 
Pruitt, 1977). The values of crop coefficient vary mainly with the crop characteristics, crop sowing or planting date, rate of crop development, length of growing season and prevailing climatic conditions. For water balance irrigation scheduling, crop evapotranspiration are estimated from crop coefficient curves, which reflect the changing rates of crop water use over the growing season. Some researchers have developed various crop coefficient equations for different crops (Elliott et al., 1988; Gheysari et al., 2006; Majnooni-Heris et al., 2012). Ko et al., (2009) determined growth stage specific crop coefficients of cotton and wheat. Senapati (1992), Steele et al., (1996) and Hanskar (1999) derived crop coefficient curves as a function of day past planting for different crops using sixth, fifth and fifth order polynomials, respectively.

Temperature is an important climatic factor that has a significant influence on crop phenology and yield of crop (Bishnoi et al., 1995) and it is a better predictor of the rate of development of crops and other organisms than calendar time. Plants have a definite temperature requirement to attain phenological stages. Growing degree-days (GDD), which is an index calculated using temperature data, is often used to estimate the time needed for a crop or other organisms to reach maturity or to reach a certain stage of development (Parthasarathi et al., 2013; Paparrizos and Matzarakis, 2017). Temperature and growing degree days (GDD) play vital roles in influencing crop development by directly affecting plant functions such as evapotranspiration, photosynthesis and plant transpiration. GDD is a useful climate impact indicator as it provides indicative information to users to manage climate risks and opportunities. According to Matzarakis et al., (2007), understanding the spatial distribution of growing degree days has importance for sustainable agricultural management, as GDD relates to the integration of growth and provides precise implications for agricultural management. Early sowing crop resulted in absorbing sufficient GDD in relatively more time while late sown crop experienced higher temperature during later stage in less time (Pandey et al., 2010).

In upcoming years, certain area will exhibit water scarcity problems due to irrigation and furthermore due to drought phenomena or decreased precipitation that may cater sustainable development of the water resources, especially in irrigated agriculture. Due to possible climate change effects and global warming, potential future increase of GDD units can lead to be more demanding that will be profitable and efficient for irrigated farming. Concept of GDD recognizes that plant development will occur only when the temperature exceeds a specific base temperature for a certain number of days. It is a measure of the heat a plant requires to mature and yield a successful crop and thus every crop needs a specific amount of GDD to enter its reproductive phase from vegetative phase. GDDs are used to predict the growth stages of crops and also useful in planning precautionary measures against insect pest and disease attacks on crops (Cesaraccio et al., 2001; Matzarakis et al., 2007; Fealy and Fealy, 2008).

In general, for a given day, growing degree days (GDD) is the difference between the average air temperature and the base temperature $\left(\mathrm{T}_{b}\right)$ for a particular crop. GDD is usually calculated on a daily basis and then accumulated during the number of days of interest. In agriculture, GDD is often also known as degree days or heat units. Due to variation in crop development rates between locations and years, thermal based indexes are used to relate crop coefficient curves more directly to phenological development. 
Cumulative growing degree days (CGDD) are commonly used as thermal based index. Vanino et al., (2015) estimated crop coefficient of table grapes vineyards based on growing degree days. Keeping in view potential impact of climate change and climate variability, scientists have tried to find out crop coefficient values of different crops as a function of cumulative growing degree days (CGDD) of crops (Bandyopadhyay et al., 2005; Hunsker, 1999; Sammis et al., 1985) in which third, fifth and third order polynomial function, respectively were found to be best fitted.

Since, wheat (Triticum aestivum L.) and maize (Zea mays L.) are important crops of Bihar during Rabi season, an experiment was conducted to determine growing degree days (GDD) requirement of wheat as well as maize and to develop crop coefficient equations as a function of cumulative growing degree days (CGDD) for estimation of crop evapotranspiration. The agro-meteorological indexes such as heat use efficiency (HUE) as well as photo thermal index (PTI) were also calculated as weather based parameters for assessing crop phenology.

\section{Materials and Methods}

A field experiment was conducted at the Water Management Research Farm $\left(25.98^{\circ} \mathrm{N}\right.$ latitude, $85.67^{\circ} \mathrm{E}$ longitude and at an attitude of 52.0 meters above the Mean Sea Level) of the then Rajendra Agricultural University, Bihar, Pusa during the Rabi season. The climate of the area concern is humid subtropical. Different meteorological parameters were recorded from the weather station situated in the University campus. The mean temperature during the growing period varied from $11.8{ }^{\circ} \mathrm{C}$ in $2^{\text {nd }}$ meteorological week to $30.1^{\circ} \mathrm{C}$ in the $17^{\text {th }}$ week. Total rainfall was $106 \mathrm{~mm}$ out of which $80 \mathrm{~mm}$ occurred during $18^{\text {th }}$ week. The pan evaporation ranged from1.07 mmday ${ }^{-1}$ in the $2^{\text {nd }}$ week to 6.28 mmday $^{-1}$ in $17^{\text {th }}$ week. The mean relative humidity was recorded as maximum $(76 \%)$ in the $1^{\text {st }}$ week and minimum $(48.4 \%)$ in the $14^{\text {th }}$ week whereas wind speed was lowest as 0.37 $\mathrm{ms}^{-1}$ in the $50^{\text {th }}$ week to $4.12 \mathrm{~ms}^{-1}$ in the $18^{\text {th }}$ week.

The experiment was laid out with five replications with plot size $5 \mathrm{~m} \times 3 \mathrm{~m}$ each. Wheat (UP-262) and maize (Laxmi) crops were raised with full agronomical management. These crops were sown on November 14 and harvested on April 12 and May 5, respectively. The measured quantity of irrigation water using a $7.5 \mathrm{~cm}$ parshall flume was applied time to time in order to bring the soil moisture level to field capacity. Soil moisture content were measured using gravimetric method on different dates prior to each irrigation during the growing season for which soil samples were collected from 0-30, 30-60, 60-90 and 90-120 cm soil depths.

Soil moisture depletion from the effective root zone depth for different periods between two successive soil sampling was calculated. In order to determine crop evapotranspiration $\left(\mathrm{ET}_{\mathrm{c}}\right)$ for all the time periods between two successive soil moisture measurement dates, components of water balance equation (Jensen, 1983) was monitored. Reference evapotranspiration $\left(\mathrm{ET}_{\mathrm{o}}\right)$ for all the periods were estimated as the product of pan evaporation and appropriate values of pan coefficients $\left(\mathrm{K}_{\mathrm{p}}\right)$. Daily pan evaporation for USWB Class-A pan data was collected from meteorological observatory of the then Crop Research Programme, Pusa. Daily relative humidity and wind velocity data were collected from meteorological observatory of the then Rajendra Agricultural University, Pusa and used for obtaining pan coefficient $\left(\mathrm{K}_{\mathrm{p}}\right)$ values for considered periods (Doorenbos and Pruitt, 1977). 
Crop evapotranspiration data determined using water balance method were used to calculate crop coefficient $\left(\mathrm{K}_{\mathrm{c}}\right)$ values for wheat and maize crops for all the time periods using following equation:

$$
K_{c}=\frac{E T_{c}}{E T_{0}}
$$

Where, $E T_{c}=$ Crop evapotranspiration $(\mathrm{mm})$ and $E T_{o}=$ Reference evapotranspiration (mm)

Crop Coefficient values thus obtained for different periods of wheat and maize were used to derive a thermal based (cumulative growing degree days) crop coefficient curve to mitigate climatic variability.

The method of obtaining growing degree days (GDD) with mean air temperature calculated from the average of minimum and maximum daily temperatures which is the most common in agricultural and phenological research (McMaster and Wilhelm, 1997; Dwyer et al., 1999; Matzarakis et al., 2007; Fealy and Fealy, 2008) was used. In this study, daily growing degree days (GDD) were estimated using following formulae (Morrison et al., 1989):

$$
\begin{aligned}
G D D & =T_{\text {Mean }}-T_{\text {Base }} \\
& =\frac{\left(T_{\text {Max }}+T_{\text {Min }}\right)}{2}-T_{\text {Base }}
\end{aligned}
$$

Where, $\mathrm{T}_{\text {Mean }}$ is mean temperature $=\left(\mathrm{T}_{\text {Max }}+\right.$ $\left.T_{\text {Min }}\right) / 2, \mathrm{~T}_{\text {Max }}=$ Daily maximum temperature $\left({ }^{\circ} \mathrm{C}\right), \mathrm{T}_{\text {Min }}=$ Daily minimum temperature $\left({ }^{\circ} \mathrm{C}\right)$ and $\mathrm{T}_{\text {Base }}=$ Base temperature $\left({ }^{\circ} \mathrm{C}\right)$ below which the process of plant growth does not progress.

Growing degree days (GDD) was calculated using the lower (base) and upper thresholds temperature (Hunsker, 1999; Matzarakis et al., 2007 and Sammis et al., 1985) considering adjustment in temperature as per requirement. If the daily minimum temperature was below base temperature $\left(T_{\text {Base }}\right)$, it was reset to base temperature before calculating average. Once the high / low temperatures have been modified (where ever needed), the average temperature for the day was computed and compared with base temperature, which was $5^{\circ} \mathrm{C}$ for wheat (Amravat et al.,2013) and $10^{\circ} \mathrm{C}$ for Maize (Grigorieva et al.,2010 and Trout et al., 2018). Likewise, if the daily maximum temperature was above upper threshold temperature, it was reset to upper threshold temperature. Daily maximum temperature usually capped at $25^{\circ} \mathrm{C}$ (McMaster and Smika, 1988) and $30^{\circ} \mathrm{C}$ (Matzarakis et al., 2007 and Trout et al., 2018), respectively for wheat and maize because most plants and insects do not grow any faster above that temperature. Daily maximum and minimum temperature data were summed up and divided by 2 to get daily mean temperature and then modified daily growing degree days were calculated as difference between mean temperature and base temperature.

Growing degree days (GDD) calculated on daily basis were accumulated for the concerned period to know the cumulative growing degree days (CGDD). The crop coefficient values were plotted with respect to cumulative growing degree days (in ${ }^{\circ} \mathrm{C}$ day). While plotting the crop coefficient values for a particular period, the mid point of that particular period (Steele et al., 1996) was taken and polynomial function of the following form was fitted to the data, keeping in view the scatter of the crop coefficient $\left(\mathrm{K}_{\mathrm{c}}\right)$ values with respect to cumulative growing degree days (CGDD):

$$
K_{c}=a_{0}+a_{1} x+a_{2} x^{2}+a_{3} x^{3}+\cdots
$$


Where, ${ }^{K}{ }_{c}=$ Crop coefficient value during the period, $\quad a_{0}, a_{1}, a_{2}, a_{3} \cdots=\quad$ Regression coefficients, and $x=$ Cumulative growing degree days (CGDD) in ${ }^{\circ} \mathrm{C}$ day

Another agro-meteorological index, heat use efficiency (HUE) was calculated using the formulae mentioned below (Amrawat et al., 2013):

$H U E=\frac{Y}{C G D D}$

Where, HUE $=$ Heat use efficiency $\left(\mathrm{Kg} / \mathrm{ha} /{ }^{\circ} \mathrm{C}\right.$ day), $\mathrm{Y}=$ Grain yield $(\mathrm{Kg} / \mathrm{ha}), \mathrm{CGDD}=$ Cumulative growing degree days $\left({ }^{\circ} \mathrm{C}\right.$ day $)$

Photo-thermal index (PTI) (degree-days/day) was calculated using the following equation (Singh et al., 2014):

PTI $=\frac{\text { CGDD }}{\text { Growh days }}$

Where, PTI $=$ Photo thermal index $\left({ }^{\circ} \mathrm{C}\right.$-day/ day), $\mathrm{CGDD}=$ Cumulative growing degree days $\left({ }^{\circ} \mathrm{C}\right.$ - day), Growth days $=$ Crop duration (days)

\section{Results and Discussion}

Table 1 and 2 represent mean temperature $\left(\mathrm{T}_{\text {Mean }}\right)$, growing degree days (GDD), accumulated growing degree days (CGDD), crop evapotranspiration $\left(\mathrm{ET}_{\mathrm{c}}\right)$, reference evapotranspiration $\left(\mathrm{ET}_{\mathrm{o}}\right)$ and crop coefficient values $\left(\mathrm{K}_{\mathrm{c}}\right)$ for different time periods of crop growing season of wheat and maize, respectively. From tables, it is obvious that crop evapotranspiration $\left(\mathrm{ET}_{\mathrm{c}}\right)$ of wheat and maize have shown an increasing trend with the advancement in crop growth up to physiological development and after that it started declining. The mean crop evapotranspiration (consumptive use) of wheat and maize were determined to be 1.0 and 1.36 mmday $^{-1}$, respectively over the growing season. Maximum value of crop evapotranspiration for the respective crops being 1.83 mmday $^{-1}$ during the period $2^{\text {nd }}$ to $15^{\text {th }}$ February (80 to 94 days after sowing) and 3.03 mmday $^{-1}$ during $15^{\text {th }}$ to $28^{\text {th }}$ March (121 to 135 days after sowing).

\section{Models for cumulative growing degree days (CGDD) crop coefficients}

Crop Coefficient $\left(\mathrm{K}_{\mathrm{c}}\right)$ values for different periods of growing season of wheat and maize were computed as ratio of crop evapotranspiration $\left(\mathrm{ET}_{\mathrm{c}}\right)$ and reference evapotranspiration $\left(\mathrm{ET}_{\mathrm{o}}\right)$. Crop coefficient of wheat (Table 1) increased gradually from a low initial value of 0.07 to a maximum of 1.02 during the period $2^{\text {nd }}$ to $15^{\text {th }}$ February ( 80 to 94 days after sowing) and after that the value started declining to attain a value of 0.22 at the time of harvest.

From Table 2, it is obvious that crop coefficient of maize was as low as 0.09 which increased to a maximum of 1.03 during the period $25^{\text {th }}$ February to $14^{\text {th }}$ March (103 to 121 days after sowing) as the crop growth advanced. Thereafter, the crop coefficient value of maize started declining sharply to carry a value of 0.29 at the time of harvest.

In this study, crop coefficient $\left(\mathrm{K}_{\mathrm{c}}\right)$ values of wheat and maize were plotted against cumulative growing degree days (CGDD) that have been presented in Fig. 1 and 2, respectively. Polynomial function was fitted to crop coefficient values in which fourth order polynomial equation yielded high value of coefficient of determination $\left(\mathrm{R}^{2}\right)$. The polynomial function relating crop coefficient values $\left(\mathrm{K}_{\mathrm{c}}\right)$ and cumulative growing degree days $\left({ }^{\circ} \mathrm{C}\right)$ were derived as follows: 
Wheat,

$$
\begin{aligned}
& K_{c}=1.65 \times 10^{-12} x^{4}-6.18 \times 10^{-9} x^{3}+6.36 \times \\
& 10^{-6} x^{2}-9.47 \times 10^{-4} x+0.0818, \mathrm{R}^{2}=0.978 \ldots(6)
\end{aligned}
$$

Maize,

$K_{c}=1.62 \times 10^{-12} x^{4}-5.02 \times 10^{-9} x^{3}+3.38 \times 10^{-}$ ${ }^{6} x^{2}+1.02 \times 10^{-3} x-0.0754, \mathrm{R}^{2}=0.949 \ldots(7)$

Where, $\mathrm{K}_{\mathrm{c}}=$ Crop coefficient and $\mathrm{x}=$ Cumulative growing degree days $\left({ }^{\circ} \mathrm{C}\right)$

Using the above equations crop coefficient value for any cumulative growing degree days can be estimated. The study will be helpful for deciding the irrigation requirement and irrigation scheduling during the life cycle of these crops on the basis of temperature data. The results of regression model of $\mathrm{K}_{\mathrm{c}}$ can therefore, be used for estimation of crop evapotranpiration for these crops to be grown in Gandak command area as well as for other areas having similar climatic conditions where such data either have not been generated experimentally or not at all available. The results revealed that during the early part of the season, the crop coefficients were more closely related to crop coefficient curve derived as a function of day after sowing (Kumar and Singh, 2007) than to GDD.

For the full season, there was very little difference in the correlations for the various models using days after sowing versus GDD which is in conformity with the findings of DeTar (2009). From crop coefficient curves, it can be said that CGDD based $\mathrm{K}_{\mathrm{c}}$ curves shown improved fit for both the crops as can be seen the scatter of crop coefficient in the derived models.

From Table 3, it is obvious that total GDD to attain crop maturity was $1906.6^{\circ} \mathrm{C}$-day and $1868.0^{\circ} \mathrm{C}$-day, respectively for wheat and maize whereas heat use efficiency (HUE) of maize $\left(1.88 \mathrm{Kg} / \mathrm{ha} /{ }^{\circ} \mathrm{C}\right.$-day $)$ was slightly greater than that of wheat $\left(1.71 \mathrm{Kg} / \mathrm{ha} /{ }^{\circ} \mathrm{C}\right.$ day) and photo thermal index of maize (10.43 ${ }^{\circ} \mathrm{C}$ - day/day) was less in comparison to wheat $\left(12.79^{\circ} \mathrm{C}\right.$ - day/day).

Table.1 Mean Temperature $\left(\mathrm{T}_{\text {mean }}\right)$, Growing Degree Days (GDD), Cumulative Growing Degree Days (CGDD) and Crop Coefficient values during different periods of Wheat

\begin{tabular}{|c|c|c|c|c|c|c|}
\hline $\begin{array}{c}\text { Duration } \\
\text { (Day after sowing) }\end{array}$ & $\begin{array}{c}\mathbf{T}_{\text {Mean }} \\
\left.\mathbf{(}^{\mathbf{C}} \mathbf{C}\right)\end{array}$ & $\begin{array}{c}\text { GDD } \\
\left({ }^{\mathbf{}} \mathbf{C}-\mathbf{d a y}\right)\end{array}$ & $\begin{array}{c}\text { CGDD } \\
\left(\mathbf{} \mathbf{}^{\mathbf{C}-\mathbf{d a y})}\right.\end{array}$ & $\begin{array}{c}\text { ETc } \\
(\mathbf{m m} / \mathbf{d a y})\end{array}$ & $\begin{array}{c}\text { ETo } \\
(\mathbf{m m} / \mathbf{d a y})\end{array}$ & $\begin{array}{c}\text { Crop } \\
\text { Coefficient, } \mathbf{K}_{\mathbf{c}}\end{array}$ \\
\hline $\mathbf{1 7}$ & 20.2 & 259.2 & 259.2 & 0.09 & 1.26 & 0.07 \\
\hline $\mathbf{3 1}$ & 17.0 & 167.3 & 426.5 & 0.22 & 0.99 & 0.22 \\
\hline $\mathbf{4 6}$ & 17.3 & 184.7 & 611.2 & 0.70 & 1.11 & 0.63 \\
\hline $\mathbf{6 3}$ & 13.8 & 150.2 & 761.4 & 0.81 & 1.05 & 0.77 \\
\hline $\mathbf{8 0}$ & 15.3 & 174.6 & 936.0 & 1.05 & 1.16 & 0.90 \\
\hline $\mathbf{9 4}$ & 16.2 & 156.7 & 1092.6 & 1.83 & 1.78 & 1.02 \\
\hline $\mathbf{1 0 3}$ & 19.1 & 126.9 & 1219.5 & 1.44 & 1.66 & 0.86 \\
\hline $\mathbf{1 2 1}$ & 18.7 & 246.9 & 1466.4 & 1.45 & 2.37 & 0.61 \\
\hline $\mathbf{1 3 5}$ & 20.1 & 210.9 & 1677.2 & 1.43 & 3.43 & 0.41 \\
\hline $\mathbf{1 4 9}$ & 21.4 & 229.4 & 1906.6 & 0.91 & 3.99 & 0.22 \\
\hline
\end{tabular}


Table.2 Mean Temperature ( $\mathrm{T}_{\text {mean }}$ ), Growing Degree Days (GDD), Cumulative Growing Degree Days (CGDD) and Crop Coefficient values during different periods of Maize

\begin{tabular}{|c|c|c|c|c|c|c|}
\hline $\begin{array}{c}\text { Duration } \\
\text { (Day after sowing) }\end{array}$ & $\begin{array}{c}\mathbf{T}_{\text {Mean }} \\
\left.\mathbf{(}^{\mathbf{0}} \mathbf{C}\right)\end{array}$ & $\begin{array}{c}\text { GDD } \\
\left.\mathbf{(}^{\mathbf{0}} \mathbf{C} \text { - day }\right)\end{array}$ & $\begin{array}{c}\text { CGDD } \\
\left(\mathbf{(}^{\mathbf{0}} \mathbf{C}-\mathbf{d a y}\right)\end{array}$ & $\begin{array}{c}\text { ETc } \\
(\mathbf{m m} / \mathbf{d a y})\end{array}$ & $\begin{array}{c}\text { ETo } \\
(\mathbf{m m} / \mathbf{d a y})\end{array}$ & $\begin{array}{c}\text { Crop } \\
\text { Coefficient, } \mathbf{K}_{\mathbf{c}}\end{array}$ \\
\hline $\mathbf{1 7}$ & 22.0 & 204.7 & 204.7 & 0.12 & 1.26 & 0.09 \\
\hline $\mathbf{3 1}$ & 17.7 & 108.0 & 312.6 & 0.24 & 0.99 & 0.24 \\
\hline $\mathbf{4 6}$ & 17.7 & 115.7 & 428.3 & 0.66 & 1.11 & 0.59 \\
\hline $\mathbf{6 3}$ & 15.2 & 88.1 & 516.4 & 0.78 & 1.05 & 0.74 \\
\hline $\mathbf{8 0}$ & 16.5 & 109.8 & 626.2 & 1.04 & 1.16 & 0.89 \\
\hline $\mathbf{9 4}$ & 17.3 & 102.4 & 728.5 & 1.82 & 1.78 & 1.01 \\
\hline $\mathbf{1 0 3}$ & 20.4 & 93.4 & 821.9 & 1.36 & 1.66 & 0.82 \\
\hline $\mathbf{1 2 1}$ & 20.3 & 185.6 & 1007.4 & 2.45 & 2.37 & 1.03 \\
\hline $\mathbf{1 3 5}$ & 22.6 & 175.9 & 1183.3 & 3.03 & 3.43 & 0.88 \\
\hline $\mathbf{1 4 9}$ & 23.9 & 194.4 & 1377.6 & 2.32 & 3.99 & 0.58 \\
\hline $\mathbf{1 7 9}$ & 26.3 & 490.4 & 1868.0 & 1.10 & 3.82 & 0.29 \\
\hline
\end{tabular}

Table.3 Heat Use Efficiency (HUE) and Photo Thermal Index (PTI) of Wheat and Maize

\begin{tabular}{|l|l|l|l|l|l|}
\hline \multicolumn{1}{|c|}{ Crop } & \multicolumn{1}{|c|}{$\begin{array}{c}\text { Crop duration } \\
(\text { day })\end{array}$} & $\begin{array}{c}\text { Total GDD } \\
\left({ }^{\mathbf{0}} \mathbf{C} \text { - day }\right)\end{array}$ & $\begin{array}{c}\text { Yield } \\
(\mathbf{K g} / \mathbf{h a})\end{array}$ & $\begin{array}{c}\text { HUE } \\
\left(\mathbf{K g} / \mathbf{h a} /{ }^{\mathbf{0}} \mathbf{C} \text {-day }\right)\end{array}$ & $\begin{array}{c}\text { PTI } \\
\left({ }^{\mathbf{0}} \mathbf{C} \text {-day/day }\right)\end{array}$ \\
\hline Wheat & 149 & 1906.6 & 3253.4 & 1.71 & 12.79 \\
\hline Maize & 179 & 1868.0 & 3506.7 & 1.88 & 10.43 \\
\hline
\end{tabular}

Fig.1 Crop coefficient curve of wheat as a function of growing degree days

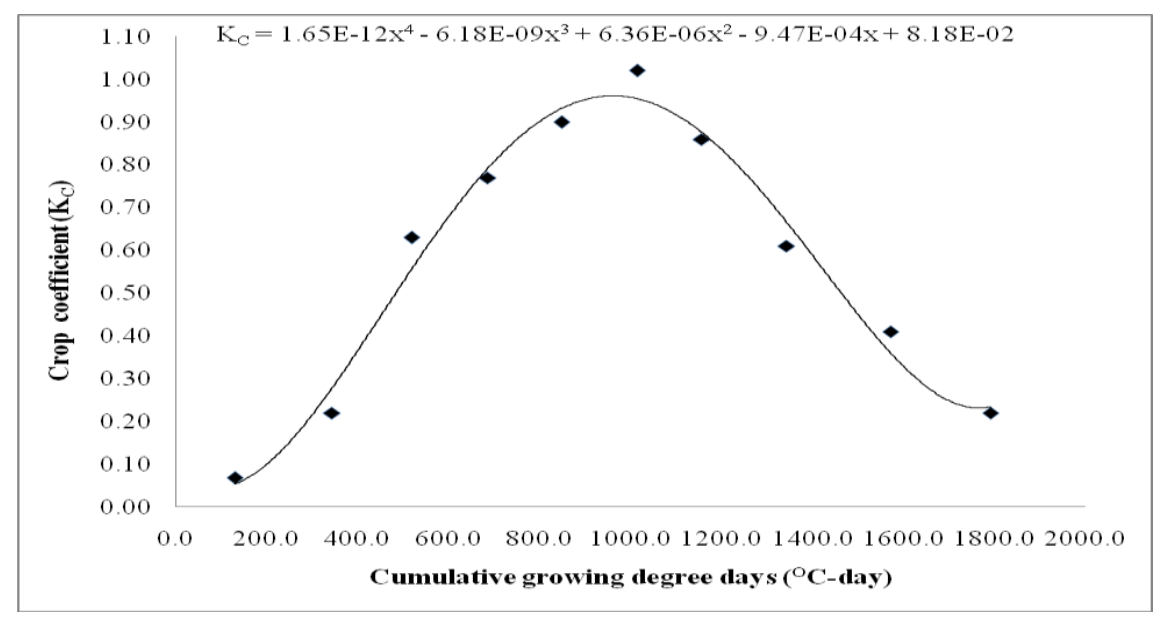


Fig.2 Crop coefficient curve of maize as a function of growing degree days



In conclusion due to possible climate change effects and global warming, potential future increase of GDD units can lead to be more demanding that will be profitable and efficient for irrigated farming. The objective of the present study was to derive model of crop coefficient based on growing degree days (GDD) for use as an agro-climatic indicator. As, climatic characteristics are related to the mean temperature of the growing season, the crop coefficient model developed as a function of cumulative growing degree days will provide valuable information for irrigation scheduling of wheat and maize. In the view of changing climate perspective in the future, GDD will increase and the existing crops can reach at maturity in shorter period that will affect distribution of the growing degree days for the crop periods. Thus, findings of this study will contribute towards the accurate interpolation and its implementation for similar climate where such research has not previously been carried out. The farmer can mitigate the negative impacts of climate on crop yield by introducing GDD based crop coefficient. Accumulated GDD had less variability than calendar days in predicting the time duration to harvest the crops and so cumulative growing degree days based crop coefficient can help in better estimation of crop evapotranspiration that will promote better irrigation management of crop against the upcoming climate change.

\section{References}

Amrawat, T., Solanki, N.S., Sharma, S.K., Jajoria, D.K. and Dotaniya, M.L.(2013). Phenology growth and yield of wheat in relation to agrometeorological indices under different sowing dates. African J. Agric. Res., 8(49): 6366-6374.

Bandyopadhyay, P.K., Mallick, S. and Rana, S. K. (2005). Water balance and crop coefficients of summer-grown peanut (Arachis hypogaea L.) in a humid tropical region of India. Irrig. Sci. 23: 161-169.

Bishnoi, O.P., Singh, S. and Niwas, R. (1995). Effect of temperature on phonological development of wheat (Triticum aestivum L.) crop in different row orientation. Indian $J$. Agric. Sci. 65:211-214.

Cesaraccio, C., Spano, D., Duce, P. and Snyder, R.L. (2001). An improved model for determining degree-day values from daily temperature data. 
Int. J. Biometeorol., 45:161-169.

DeTar, W. R. (2009). Crop coefficients and water use for cowpea in the San Joaquin Valley of California. Agric. Water Mangt., 96:53-66.

Doorenbos, J. and Pruitt, W.O. (1977). Crop water requirements. FAO, Irrig. and Drainage Paper No. 24, Rome: 144 pp.

Dwyer, L.M., Steward, D.W., Carrigan, L., Ma BL Neave, P. and Balchin, D. (1999). Guidelines for comparisons among different maize maturity rating systems. Agron. J., 91:946-949

Elliott, R. L., Harp, S.L., Grosz, G.D. and Kizer, M.A. (1988). Crop coefficients for peanut evapotranspiration. Agric. Water Mangt., 15(2): 155-164.

Fealy, R., Fealy, R.M. (2008). The spatial variation in degree days derived from locational attributes for the 1961 to 1990 period. Iranian J. Agric. Food Res., 47:1-11.

Gheysari, M., Mirlatfi, S.M., Homaee, M. and Asadi, M.E. (2006). Determination of crop water use and crop coefficient of corn silage based on crop growth stages. Iranian J. Agric. Eng. Res., 7(26): 125-142.

Grigorieva, E.A., Matzarakis, A. and de Freitas, C.R. (2010). Analysis of growing degree-days as a climate impact indicator in a region with extreme annualair temperature amplitude. Clim. Res., 42: 143-154.

Hunsker, D.J. (1999). Basal Crop coefficients and water use for early maturity cotton. Trans. ASAE, 42(4):927-936.

Jensen, M.E. (1983). Design and operation of farm irrigation systems. ASAE, Monograph No.3, Michigan, USA, p829.

Ko, J., Piccinni, G., Marek, T. and Howell, T. (2009). Determination of growthstagespecific crop coefficients $\left(\mathrm{K}_{\mathrm{c}}\right)$ of cotton and wheat. Agric. Water
Mangt., 96: 1691-1697.

Kumar, J. and Singh, A.K.P. (2007). Crop coefficient models of wheat and maize for irrigation planning in Gandak Command. J. of Ind. Water Resour. Soc., 26(1-2):14-15.

Majnooni-Heris, A., Sadraddini, A.A., Nazemi, A.H, Shakiba, M.R., Neyshaburi, M.R. and Tuzel, I.H. (2012). Determination of single and dual crop coefficients and ratio of transpiration to evapotranspiration for canola. Annals of Bio. Res., 3 (4): 1885-1894.

Matzarakis, A., Ivanova, D., Balafoutis, C. and Makrogiannis, T. (2007). Climatology of growing degree days in Greece. Clim. Res., 34: 233-240.

McMaster, G.S. and Smika, D.E. (1988). Estimation and evaluation of winter wheat phenology in the central Great Plains. Agric. Meteorol, 43:1-18.

McMaster, G.S. and Wilhelm, W.W. (1997). Growing degree-days: one equation, two interpretations. Agric.\& Forest Meteorol., 87:291-300.

Morrison, M.J., McVetty, P. B. E. and Shaykewich, C.F. (1989). Determination and verification of a baseline temperature for the growth of Westar summer rape. Canadian $J$. Plant Sci, 69: 455-464.

Pandey, I.B., Pandey, R.K., Dwivedi, D.K. and Singh, R.S. (2010). Phenology, heat unit requirement and yield of wheat varieties under different cropgrowing environment. Indian J. Agric. Sci., 80:136-140.

Parthasarathi, T., Velu, G. and Jeyakumar, P. (2013). Impact of Crop Heat Units on Growth and Developmental Physiology of Future Crop Production: A Review. Res. \& Rev.: A Journal of Crop Sci. and Tech., 2 (1):1-11.

Paparrizos, S. and Matzarakis, A. (2017). 
Present and future responses of growing degree days for Crete Island in Greece. Adv. Sci. Res., 14: 1-5.

Sammis, T.W., Mapel, C.L., Lugg, D.G., Lansford, R.R. and McGuckin, J.T. (1985). Evapotranspiration crop coefficients predicted using growing degree days. Trans. ASAE, 28 (3): 773-780

Senapati, P.C. (1992). Development of crop coefficient models for irrigation command area of Kenarapara canal in Orissa. J. Indian Water Resources Soc., 12 (1\&2): 10-16.

Singh, M.P., Lallu and Singh, N.B. (2014).Thermal requirement of indian mustard (Brassica juncea) at different phonological stages under late sown condition. Indian J. Plant Physiol., 19(3): 238-243.
Steele, D.D., Sajid, A.H. and Prunty, L.D. (1996). New corn evapotranspiration crop curves for southeastern North Dakota. Trans. ASAE, 39 (3): 931936.

Vanino, S., Pulighe, G., Nino, P., Michele, C.D., Bolognesi, S.F. and D’Urso, G. (2015). Estimation of evapotranspiration and crop coefficients of Tendone Vineyards using multi-sensor remote sensing data in a Mediterranean environment. Remote Sens., 7: 14708-14730.

Trout, T. J., ASCE, F. and De Jonge, K.C. (2018). Crop water use and crop coefficients of Maize in the Great Plains. J. Irrig. Drain. Eng., 144(6): 04018009-1-13.

\section{How to cite this article:}

Jeetendra Kumar, U. N. Umesh and Singh, A. K. P. 2020. Derivation of Crop Coefficient Model of Wheat and Maize Using Growing Degree Days to Mitigate Climatic Variability. Int.J.Curr.Microbiol.App.Sci. 9(10): 2915-2924. doi: https://doi.org/10.20546/ijcmas.2020.910.351 